\title{
Adaptable and Instagrammable features in the interior of a University Library
}

\author{
A.D. Purnomo, N. Laksitarini \& A.N. Jihad \\ Telkom University, Bandung, Indonesia
}

\begin{abstract}
The existence of a library is very important for the sustainability of a university. However, in reality there is still the assumption that a library is just a complement to accreditation. In addition, libraries aren't being used as much by current millennial academics who are more interested in and pampered by gadgets than visiting to the library. The ease of getting information, entertainment, and socialization can be found online, therefore the university library needs to change from rows of bookshelves and tables to a more varied of layout. This paper examines the interior of modern and contemporary university libraries. Being adaptable and instagrammable becomes one of the considerations of a library's updated interior. The research methodology is implemented using the descriptive qualitative method at the Open Library at Telkom University, Bandung. The conclusion of this paper is that a university library must support "work-leisurelearning" activities.
\end{abstract}

Keywords: adaptable, instagrammable, interior, library

\section{INTRODUCTION}

The changing world of technology requires that every aspect of our lives to adapt, and universities are no exception. The university campuses of old must transform themselves into appearing young, energetic, and fun. Their learning atmospheres must be created with enthusiastic "work-leisurelearning" in mind so as to appeal to the current generation cof college students (Kasali 2013).

The existence of a library is at the very core of a higher education institution and can been seen as the "the heart of university" (Darwanto 2015; Mubasyaroh 2016). The library is a vital facility for the improvement and sustainability of a university. But in reality, many at the university assume that a library only acts a complement for the school and that its function is sub-optimal at best. Few in the academic community take advantage of that facility. The academic community, especially lecture and college students, are dominated by millennials who are all-too familiar with electronic gadgets. They are the modern generation born between 1980-2000, and, generally, this generation tends to place more trust in user-generated content (UGC) than unidirectional information, prefers cellphones to TVs, must have social media, do not like to read conventionally, more flexible with commitment at works, conduct cashless transaction, know more about technology, utilizing information, and communication technology, multitask, and tend to be lazy and consumptive (Hidayatullah 2018). Therefore, this generation sees the world differently than previous generations, lives in an online world, and uses social media as a tool for expression and to make a living. (Kasali 2017).

The interior of a building is a form of a built environment that embodies all human activities. The physical, physiological, and psychological needs of humans factor into the design of a room (Rengel 2016). The library is not only a place but also a space that encompasses a lot of activities, from user interactions to a room for creating a learning atmosphere. As the millennial generation has very different way of studying than their previous generations (Ertel 2019; Priyanto 2015), a modern library's interior needs to support their needs. 
Andrew McDonald said there are ten factors plus one that important to note in the ideal library interior: functional, adaptable, accessible, varied, interactive, conducive, environmentally suitable, safe and secure, efficient, equipped with information technology, and the extra factor "the oomph' or 'wow' (Letimer 2007). Adaptable is important for libraries to be able to change and adapt to the changing times. While the factor 'the oomph' or with terms 'wow' means that the library not only becomes an inspirational and fun room but it also gives spirit for the academic community. In the end, the library has the function to not only as a place to lend a book and read it but can also be a place to create an atmosphere 'work-leisure-learning'. For it, interior design for the library is important to note character from the user, such as age, gender, culture, and other (Majidah 2019).

\section{METHOD}

This paper analyzes the interior design of the Open Library at Telkom University (Openlib Tel-U) in Bandung, West Java. The modern library is located at Telecommunications Street no.1, Sukapura, Terusan Buah Batu, Bandung, and encompasses an area of $3200 \mathrm{~m}^{2}$ with a total collection of 150,971 books and 95,891 titles. The vision of Openlib Tel-U is to become the leader of the scientific center with world-class governance. The missions are active in knowledge acquisition, knowledge management, and knowledge sharing, active in reading and writing improvement in the community, and working together with institutions that have the same vision. The interior design has a "green futuristic" concept and international standard.

The descriptive qualitative research method was used. The primary data was obtained by field observation and interviews with the developer and respondents who are students. Secondary data was obtained from printed as well as electronic (internet) literature. Printed literature includes reference books and newspapers while electronic literature involves websites, profile videos, Instagram, blogs, social media, scientific journals, and online proceedings.

\section{RESULT}

\subsection{Interior of Openlib Tel-U}

The interior of Openlib Tel-U utilizes green futuristic and modern concepts. The interior layout is split into three areas. The left side consists of a special collection room, a reading area, library café, and discussion rooms. The right side is utilized for general book collections, a reading area, discussion rooms, a mini theater, and a sit-down reading area. The middle area consists of the circulation area and a reading area equipped with tables, chairs, and sofas, utilizing an open area without any partitions. Several corners of the area are attractively designed with sofas and bookshelves. The interior concept minimalizes the use of a partition, and only discussion rooms have a glass partition. The application of colorful and bright colors on the wall provide fresh and cheerful stimulation for the users.

\subsection{Adaptable for Library interior}

Being adaptable means being able to easily and quickly adjust, and be inconsistent and flexible. Adaptable concepts can also mean something that is not monotonous. The nature of adaptability in a room includes three components: expandability, convertibility, and versatility. Adaptable spaces can accommodate expansion, change in function, and provide multifunctional space (Ballast 2007). The adaptable concept in the Openlib Tel-U interior was applied with minimal implementation of a massive wall so as to maximize the use of an open space concept. The impressions of an adaptable concept and the feeling of friendliness can be experienced once entering the center area. A curved partition gives a familiar but not rigid impression. The ability to change or expand in the future as needs change was also considered. The computer area for internet browsing was restricted with 


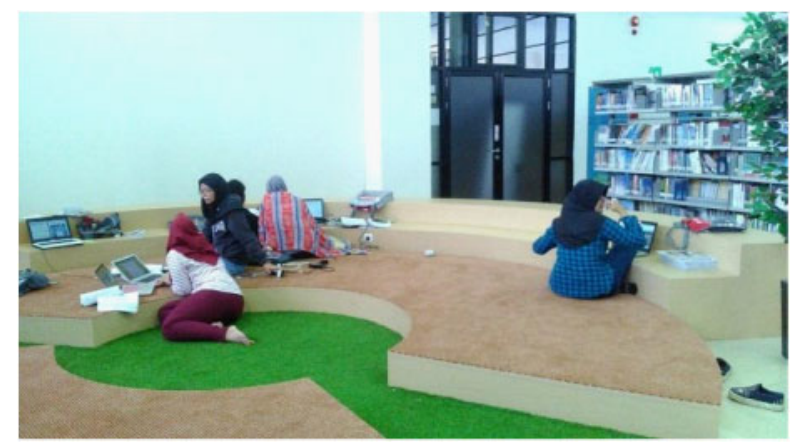

Figure 1. The reading area provides an information feeling. (Source: desinovs.blogspot.com).

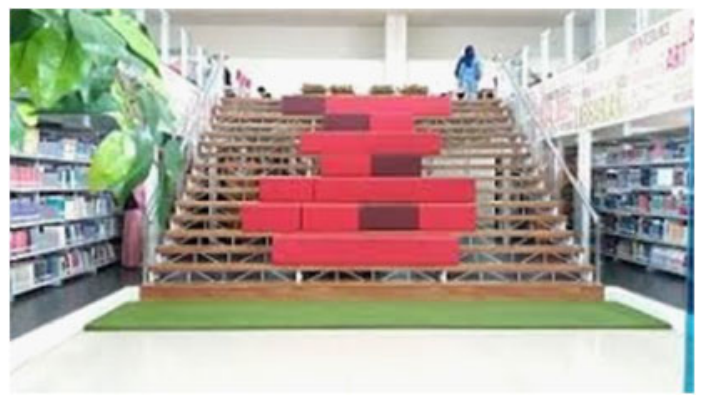

Figure 2. The steps used to sit. (Source: openlibrary.telkomuniveristy.ac.id).

an iron pipe mounted vertically, as if a giant birdcage was surrounding the computer desk. The reading area with bookshelves is separated with different floor heights and does not use a closed partition.

The adaptable concept was also seen in the reading area with the procurement of furniture variations. There are several reading areas and discussions room with no seats. This situation giaves an informal and more relaxed impression. Meanwhile, near the bookshelf area there is a multifunctional stair. That stair connects the bookshelf area to the mezzanine floor which uses the reading area. The stair is used as the way to go up and down to the mezzanine floor. Some part of the stairs are utilized as seating and reading areas. Some areas are equipped with a sofa for reading with in more relaxed position. The rest of the area consists of tables and upright chairs for single users or groups.

Most furniture layout and interior elements are in the form for a cursve, following the room's shape to create an exciting and fun atmosphere. The atmosphere is informal, curved in shape, and furniture can be dragged out for interaction and to attract communication. Also, the material used in the seating facility at the lobby and book display are made of materials that give a bright and light impression. Some area even use a short table for a writing facility so the user can sit on the floor that utlizes synthetic grass. The use of colors that are not monotonous, and reading area placement makes user activity more interactive and supports a "work-leisure-learning" atmosphere.

\subsection{Instagrammable}

Instagram is one of the social media apps that is very popular with the millennial generation. Instagram is a platform whose usage is similar to their character - energic and up to date. The applicative social media is used to represent the user themself. Instagram makes it possible for a user to post a photo or video so that another follower can see and comment on it. The satisfaction 


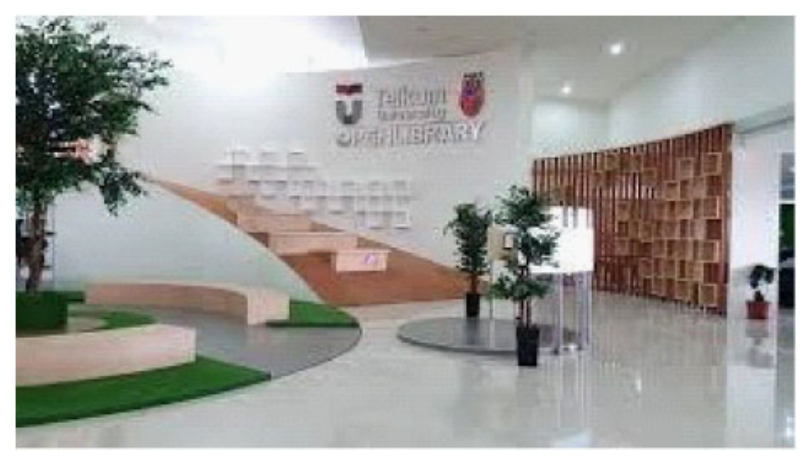

Figure 3. The midlle area as a photo spot. (Source: openlib.telkomuniveristy.ac.id).

of the user on Instagram is the effort to get the angle of shooting a photo as good as possible to appeared very excited or as it is known: "instagrammable". Millenials will always stay at a place for a long time if get they are instagrammable sites. Instagrammable pictures can be realized via an interesting interior pattern.

Based on student respondents at Telkom University, an area that is considered quite interesting and instagrammable is the middle area of Openlib Tel-U due to its stair and ramp that connect it to the mezzanine, the birdcage area, the colors used, and the corner reading area. The middle area of the Openlib Tel-U is the first area that vistor enters into. The circulation in the service room is radial, and its counter table is marked by a curve as a focal point. The stair and ramp on the left side has a stair and ramp is seen as an instagrammable spot because its radial pattern is quite interesting. The use of the green artificial grass floor covering provides a connection to a futuristic green concept.

The entrance of the book collection area also has an instagrammable design. Besides the function as an access to the reading room in the upper floor, the stair can be used as a seat. The red color on the cushions is in contrast with the reading room area. This is the focal point, so the sub-stair is used as a photo spot area.

The birdcage area is shaped as a radial area that is made similar to a birdcage by using iron pipe and finished a white color. It is an area for browsing the internet and is very memorable and always remembered by librarians because it is unique and instangrammable.

The discussion rooms are available for visitor use and and the sizes of the rooms vary. Each room uses a different color and features inspirational quotes on the wall. By using a fresh color, it makes the atmosphere of the discussion room more lively. Color plays an important role and has the extraordinary power to remove emotionality. The colorful discussion rooms are also photo spots used by the students.

\section{CONCLUSION}

The library at a university provides a big contribution to the provision of learning resources and information access for the academic community. A library with adaptable and instagrammable concept for the interior can create an interesting, and not monotonous, atmosphere. The use of fresh color and a curved shape concept for furniture and Openlib the Tel-U layout become important aspects of creating a fun learning atmosphere. Variation in learning areas provide college students with a way to obtain an alternative are for reading book or taking a test. Therefore, the interior of the library can support "work-leisure-learning", which is very suitable for the millennial generation. It is the hope that all of this will attract students to visit the library more often. 


\section{REFERENCES}

Darwanto, Utami, Anggun Kusumah Tri, and Gusniawati, Nia. 2015. Pedoman Penyelenggaraan Perpustakaan Perguruan Tinggi. Jakarta: Perpustakaan Nasional Republik Indonesia.

Ertel, Monica. 2019. Change Literacy: Digital, Collaborative, Creative. Summary of the 2019 World Library and Information Congress Knowledge Cafe Program, August 27, 2019: Athens, Greece.

Hidayatullah, Syarif, Abdul Waris, Riezky Chris Devianti, Syafitrilliana Ratna Sari, Irawan Ardi Wibowo, and Pande Made PW. 2018. Perilaku Generasi Milenial Dalam Menggunakan Aplikasi Go-Food. Jurnal Manajemen dan Kewirausahaan, 6(2): 240-249.

Kasali, Rhenald. 2013. Change! Jakarta: PT. Gramedia Pustaka Utama.

Kasali, Rhenald. 2017. Disruption. Jakarta: PT. Gramedia Pustaka Utama.

Letimer, Karen and Hellen Niegaard. 2007. IFLA Library Building Guidelines: Developments and Reflections. Munchen: K. G. Saur Verlag.

Majidah, M., Hasfera, Dian, and Fadli, M. 2019. Penggunaan Warna Dalam Desain Interior Perpustakaan Terhadap Psikologis Pemustakala. Jurnal Bimbingan dan Konseling, 4(2):95-106.

Mubasyaroh. 2016. Pengaruh Perpustakaan Bagi Peningkatan Mutu Pendidikan Perguruan Tinggi. Jurnal Libraria, 4(1):77-104.

Priyanto, Ida F. 2015. Perkembangan Baru Dalam Dunia Perpustakaan. Makalah Seminar Universitas Brawijaya, Malang, September 29, 2015.

Rengel, Roberto J. 2016. The Interior Plan - Concepts and Exercises. New York: Bloomsbury. 